\title{
Review
}

Jamie M. Kramer*

\section{Epigenetic regulation of memory: implications in human cognitive disorders}

\begin{abstract}
Epigenetic modification of chromatin structure is an important mechanism in the regulation of gene expression. Recent studies have shown that dynamic regulation of chromatin structure occurs in response to neuronal stimulation associated with learning and memory. Learning-induced chromatin modifications include DNA methylation, histone acetylation, histone phosphorylation and histone methylation. Studies in animal models have used genetic and pharmacological methods to manipulate the epigenetic machinery in the brain during learning and memory formation. In general, these studies suggest that epigenetic regulation of chromatin structure is essential for long term memory (LTM) consolidation, which is known to require new gene transcription. Analysis of animal models has also implicated epigenetic mechanisms in impaired cognition associated with aging, neurodegenerative disease, and intellectual disability (ID). Recently, it has been shown that a subset of ID disorders and autism are caused by disruption of specific chromatin modification complexes that are involved in nuclear hormone receptor mediated transcriptional regulation. This review provides an overview of chromatin modifications that are implicated in learning and memory and discusses the role of chromatin modifying proteins in learning-induced transcriptional regulation and human cognitive disorders.
\end{abstract}

Keywords: cognitive disorders; epigenetics; intellectual disability; learning and memory.

\footnotetext{
*Corresponding author: Jamie M. Kramer, Department of Human Genetics, Nijmegen Centre for Molecular Life Science, Donders Institute for Brain Cognition and Behaviour, Radboud University Nijmegen Medical Centre, Geert Grootplein 10, NL-6525 GA Nijmegen, The Netherlands, e-mail: j.kramer@gen.umcn.nl
}

\section{Introduction}

The cellular and molecular basis of learning and memory is a topic that has fascinated neuroscientists for decades. The sheer complexity of how we interpret, remember, and forget our experiences seems impossible to understand at the cellular and molecular level. Yet, through the use of many different learning and memory paradigms in different model organisms, we are beginning to have a basic understanding of the molecular changes that allow neurons to create and store memories $(1,2)$. Much of the work discussed here involves contextual fear conditioning in rodents (mice and rats) as a model for hippocampus-dependent associative memory (1), but studies using spatial learning (3), novel object recognition (4), and conditioned courtship behavior in Drosophila (5), are also cited. Although there may be different mechanisms at work in different brain regions for different learning tasks, this review attempts to generalize the different learning paradigms according to their similarities. Most learning paradigms do follow a general pattern consisting of a 'training' period, followed by 'testing' for a behavioral read-out at different time points after training. Although there is no standard definition of the different phases of memory, it is commonly accepted that long term memory (LTM), ranging from 1 day to several months, requires gene transcription, while short term memory (STM), usually immediately after or within a few hours of training, does not.

Some of the signaling pathways that allow neurons to acquire and store memories have been deduced using genetic or pharmacological manipulations at different time points during and after training $(1,2)$. At the molecular level, memory acquisition seems to be initiated when post-synaptic NMDA-type receptors (NMDAR) are activated, leading to an influx of $\mathrm{Ca}^{2+}$ into the neuron (Figure 1). Increased $\mathrm{Ca}^{2+}$ leads to the activation of kinases, like the $\mathrm{Ca}^{2+} /$ calmodulin-dependent protein kinase II (CaMKII) (6). CaMKII kinase activity contributes to STM formation, through relatively fast acting mechanisms, such as phosphorylation of AMPA-type receptors (AMPAR), resulting in an increased localization of AMPAR in the postsynaptic membrane and strengthening of the activated synapse $(1,2,6)$ (Figure 1). Over time, this newly acquired memory is consolidated into LTM, in a process that is dependent on gene transcription. This learning-induced gene transcription is in part, regulated through $\mathrm{Ca}^{2+}$-activated 


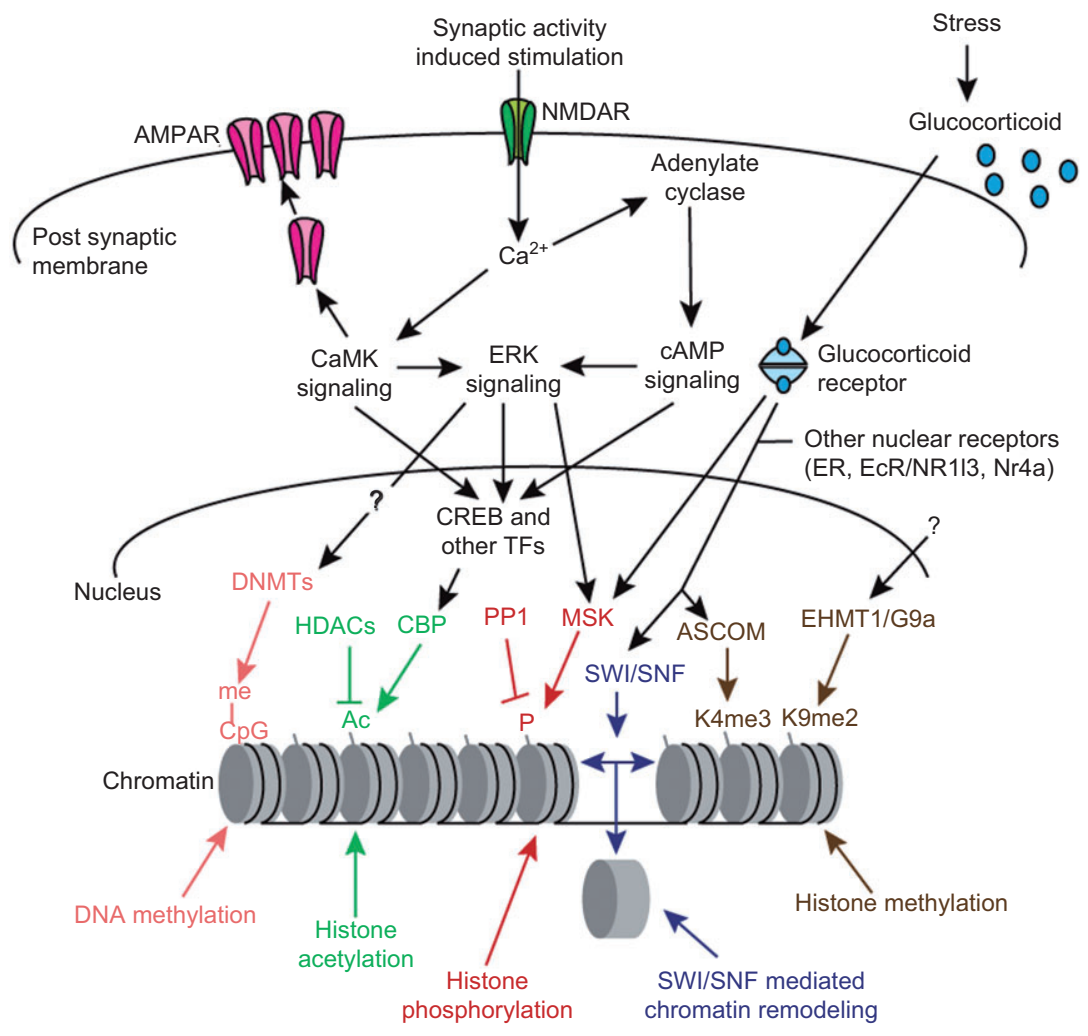

Figure 1 Signaling pathways and chromatin modifications in learning, memory, and human cognition.

Synaptic activity induced stimulation of NMDA-type receptors (NMDAR) leads to an influx of calcium ions ( $\mathrm{Ca}^{2+}$ ) into the neuron. $\mathrm{Ca}^{2+}$ activated signaling pathways influence short-term memory by promoting recruitment of AMPA-type receptors (AMPAR) to the post-synaptic membrane. $\mathrm{Ca}^{2+}$ mediated signaling pathways also influence gene transcription by inducing epigenetic modifications. Several nuclear receptors are also associated with learning and memory processes including the glucocorticoid receptor, which is activated in response to stress. Chromatin modifications depicted here include a subset that is associated with learning and memory processes and/or human cognitive disorders.

signaling mechanisms, including CaMK signaling, cyclic AMP (cAMP) signaling, and extracellular signal related kinase (ERK) signaling $(1,2,7)$ (Figure 1). These pathways converge on the cAMP response element binding protein (CREB), a transcription factor that regulates many target genes in the formation of LTM (8). Although CREB is the best characterized transcription factor involved in the regulation of LTM, it is not the only transcription factor that responds to cellular signaling pathways activated by learning (7). In general, very little is known about the full extent of transcriptional regulation that is required for memory formation, or about CREB-independent mechanisms in LTM. It is clear, however, that diverse forms of epigenetic regulation are essential in this process (9, 10) (Figure 1). This review highlights work performed in model organisms over the last decade that makes significant progress in uncovering the role of epigenetic regulators and chromatin modifications in various types of learning and memory. The importance of these processes in human cognitive function is also discussed by examining recent literature implicating epigenetic regulation in the occurrence of autism and intellectual disability (ID), which is a cognitive disorder that is present in $1-3 \%$ of the population and is defined by low IQ $(<70)$ and an early age of onset ( $<18$ years).

\section{Epigenetic modification of chromatin structure}

The term epigenetics ('above genetics') was initially coined by C.H. Waddington in his effort to explain how cells containing identical genetic information can be so diverse in form and function (11). It is now known that development and cellular differentiation are dependent on epigenetic mechanisms for the maintenance of gene expression profiles and it is hypothesized that each cell 
type may have a distinct gene expression profile that contributes to its characteristic features (12). Epigenetic modifications allow for heritability of chromatin structure and maintenance of gene expression patterns through many generations in dividing cells. Chromatin is made up of DNA and histone proteins. Histone proteins $\mathrm{H} 2 \mathrm{a}, \mathrm{H} 2 \mathrm{~b}, \mathrm{H} 3$, and $\mathrm{H} 4$ form an octamer, which is wrapped by 146 base pairs of DNA to form a nucleosome. Epigenetic modifications can alter chromatin structure to produce densely packed 'repressive' chromatin or loosely packed 'active' chromatin. Three important types of epigenetic modification that are pertinent to this review include: (1) DNA methylation; (2) post-translational modification of histone proteins; and (3) ATPdependent chromatin remodeling. A comprehensive overview of different epigenetic modifications and their effects on the chromatin environment and transcription has been reviewed elsewhere (13-15). Specific types of epigenetic modification that have been directly implicated in learning and memory are discussed below. These include DNA methylation, histone acetylation, histone phosphorylation, and histone methylation (Figure 1).

\section{DNA methylation and the formation of long term and distant memories}

DNA methylation is catalyzed by DNA methyltransferases (DNMTs) and occurs on cytosine bases of $\mathrm{CpG}$ dinucleotides. $\mathrm{CpG}$ dinucleotides are enriched at gene promoters in so-called 'CpG islands' and methylation of these $\mathrm{CpG}$ rich regions can repress transcription by directly limiting access of transcription factors to promoters and/or by promoting the recruitment of methyl CpG-binding proteins (MeCP), which can in turn recruit larger repressive complexes (16). DNA methylation also occurs outside promoters regions and although the function of non-promoter DNA methylation is not well understood, it has been associated with transcriptional activation (17, 18). Furthermore, MeCP2 has been shown to recruit both activators and repressors of transcription (19), suggesting that DNA methylation can serve diverse roles in different contexts. DNA methylation appears to play a role in human cognitive function, since mutations affecting the methylation machinery (DNMT3b) and proteins that bind to methylated DNA (MeCP2), have been shown to cause ID $(20,21)$. Defects in DNA methylation are also thought to play a role in neurodegeneration in Alzheimer's disease, due to Alzheimer's-associated defects in the metabolism of methyl-donor molecules (22-24).

DNA methylation has traditionally been viewed as a stable epigenetic mark, however, many recent studies have shown that DNA methylation is plastically regulated, especially in neurons (25-27). Neuronal activation in mouse dentate granule neurons induces dynamic remodeling of genomic DNA methylation profiles, with methylation changes occurring largely outside of $\mathrm{CpG}$ islands in association with brain specific genes (27). Although the effect of these methylation changes on gene expression is not known, this work shows that DNA methylation is plastically regulated in response to neuronal activity. DNA methylation is also altered in the rat hippocampus in response to contextual fear conditioning and induction of long-term synaptic potentiation (LTP) $(25,26,28)$, a form of synaptic plasticity associated with memory (29). Accordingly, knock-out of components of the methylation machinery (Dnmt1 and Dnt3a) in mice and pharmacological inhibition of DNMTs in the rat hippocampus, results in defects in fear conditioned LTM and hippocampal LTP $(25,26,28,30)$. Dnmt3a expression is increased in the rat hippocampus in response to fear conditioning and pharmacological activation of ERK signaling, an important molecular pathway in memory consolidation $(25,28)$. This suggests that learning-induced alterations in DNA methylation may result from learning-induced alterations in expression of the methylation machinery. Although ERK signaling has been implicated in this process, it is still unclear precisely how learning-induced neuronal plasticity leads to DNMT activation and altered DNA methylation (Figure 1).

Changes in hippocampal DNA methylation in response to synaptic activity or learning, are relatively short-lived, lasting in the order of hours or days $(25,27,31)$, yet contextual fear memory in rats can last for many months. This long lasting remote memory is thought to reside in the prefrontal cortex and it was recently shown that pharmacological inhibition of DNMTs in this brain region, 1 month after fear conditioning, eliminated the ability to recall remote memories (31). Thus, DNA methylation in certain brain regions seems to act as a long lasting trace of distant memories. This is supported by the demonstration that DNA methylation in an adult rat brain is influenced by the amount of licking and grooming that the mother rat performs during the first weeks of life (32). DNA methylation is also altered in post-mortem brains of suicide victims that had reported childhood abuse, suggesting that it also 
influences long-term behavioral effects of distant experiences in humans (33).

\section{Histone modifications in learning and memory}

\section{Histone acetylation}

Histone acetylation in the genome is regulated through a balance between histone acetyltransferases (HATs), which add acetyl groups, and histone deacetylases (HDACs), which remove them. Acetylation can occur at many different lysine residues in the $\mathrm{N}$-terminal tails of histone proteins and this acetylation is usually associated with active transcription. It has been proposed that negatively charged acetyl groups disrupt DNA-histone interactions and loosen chromatin structure to allow for active gene transcription (34), however, acetylated histone residues may also provide very specific binding platforms for components of the transcriptional machinery and epigenetic regulatory complexes, such as the switch/sucrose non-fermentable (SWI/SNF) ATPase complex (35). Disruption of the histone acetylation machinery through mutations in genes encoding either HATs [CREB binding protein (CBP) and p300] or HDACs (HDAC4) causes ID in humans (36-38).

Many studies suggest that the interplay between HATs and HDACs is critical for LTM. Histone H3 acetylation increases in the rat hippocampus in response to contextual fear conditioning. This induction seems to be important for memory consolidation and is dependent on known memory related signaling components, such as NMDAR and ERK signaling $(39,40)$. ERK signaling can affect histone acetylation through direct activation of CREB, a transcription factor that is critical for LTM formation (8). Activated CREB affects acetylation of specific target genes by recruitment of CBP, a HAT that is mutated in Rubinstein Taybi syndrome, an ID disorder (36). In mice, heterozygous mutations in CBP cause LTM defects in an object recognition assay $(41,42)$, which were rescued by pharmacological activation of CREB (43). The requirement of CBP in object recognition LTM is dependent on its ability to bind to CREB and on its HAT activity $(44,45)$, suggesting that CBP regulates LTM by acetylating histones at CREB target genes. In addition, the expression level of CBP, p300 (a CBP paralog), and the p300/CBP-associated factor (PCAF), was shown to be increased during spatial memory consolidation in rats. This increased expression of the acetylation machinery was associated with increased $\mathrm{H} 2 \mathrm{~B}$ and $\mathrm{H} 4$ acetylation in the rat hippocampus and was shown to be defective in a hippocampal denervation model for Alzheimer's disease that is defective in spatial memory consolidation (46). These studies have revealed a specific signaling pathway, which regulates memory, in part, by induction of histone acetylation (Figure 1).

Many studies have shown that promoting histone acetylation in the brain can improve memory. HDAC inhibitors (HDACi) increase histone acetylation by inhibition of the molecular machinery responsible for removing acetyl groups from histone proteins. Treatment of rats and mice with HDACi can improve memory in wild type animals in several learning paradigms, including contextual and cued fear conditioning (40, 47-53). Furthermore, mice with deletion of the Hdac2 gene showed enhanced LTM, in response to fear conditioning, while overexpression of $\mathrm{Hdac} 2$ in the mouse brain decreased LTM (47). Several other studies have also indicated that limiting HDAC2 levels is critical for optimal cognitive ability during aging (54-56). HDAC2 was found to be elevated in Alzheimer's disease brains and in mouse models for neurodegenerative disease, which have defects in spatial memory and fear conditioning (54). Reducing Hdac2 expression in these mouse models by short hairpin RNA (shRNA) knockdown fully abolished neurodegeneration-associated defects in fear conditioning and spatial memory, further supporting the idea that increased expression of HDACs is an important mechanism contributing to cognitive decline in neurodegenerative disease (54). In a mouse model for age dependent cognitive decline, aged mice with cognitive defects did not exhibit the normal pattern of increased histone acetylation and altered gene expression in response to fear conditioning, and these age-dependent molecular defects were also rescued by HDACi treatment (57). Furthermore, HDACi treatment has been shown to rescue LTM and LTP defects in many other rodent models for neurodegenerative disease, age dependent cognitive decline, and ID $(41,55,58-61)$. Taken together, these studies suggest that modulation of chromatin structure through histone acetylation is an important process in learning and memory and may be relevant to cognitive disorders, such as ID, neurodegenerative disease, and age dependent cognitive decline. The observation that HDACi treatment can improve cognitive function in wild type animals and in disease models with cognitive deficits, suggests that manipulation of epigenetic pathways is a potential avenue for the treatment of cognitive dysfunction.

\section{Histone phosphorylation}

The role of histone phosphorylation in transcriptional regulation is not well understood, however, histones can 
be phosphorylated at many residues and can play a role in diverse biological processes including chromosome condensation during cell division, DNA damage repair, and transcription (62). In studies involving learning and memory, phosphorylation of histone H3S10 is most commonly described and phosphorylation at this residue seems to be associated with transcriptional activation. H3S10 may affect transcription by directly altering chromatin structure, or through recruitment of other proteins and crosstalk with other epigenetic marks (62).

There are many parallels between histone phosphorylation and histone acetylation with respect to learning and memory. As with histone acetylation, H3S10 phosphorylation is increased in the hippocampus in response to fear conditioning in an ERK and mitogen and stress activated protein (MSK) dependent manner $(39,51)$. MSK is a histone kinase that is activated by ERK signaling (Figure 1). Interestingly, decreasing histone phosphorylation through mutations in MSK causes defects in the spatial memory in mice, while enhancing histone phosphorylation by deletion of the histone phosphatase $P P 1$ can improve spatial memory (63-65). Thus, in parallel with histone acetylation, increased histone phosphorylation appears to enhance memory formation.

\section{Histone methylation}

Histone methylation occurs on lysine and arginine residues and is regulated by histone methyltransferases (HMTs) and histone demethylases (HDMs). Methylation at different lysine residues within the $\mathrm{N}$-terminal tails of histones can have different effects on gene transcription; for example, H3K4 trimethylation is associated with active transcription, while $\mathrm{H} 3 \mathrm{~K} 27$ trimethylation is associated with transcriptional repression $(13,15,66)$. Methylated lysine residues can be present in either a mono-, di-, or tri-methylated state and the number of methylation groups at a particular residue can have different effects with respect to transcription. For example, H3K9 tri- and di-methylation are associated with repressive heterochromatin, while H3K9 mono-methylation is found at active genes (66). Many different mediators of histone methylation have been implicated in ID, including the HDMs, Jumonji/ARID domain-containing protein 1c (JARID1c) and PHD finger protein 8 (PHF8), and the HMTs, euchromatin histone methyltransferase 1 (EHMT1), nuclear receptor binding SET domain protein 1 (NSD1), mixed lineage leukemia 2 (MLL2), and MLL3, suggesting that these modifications can play a role in human cognitive function (67-73).
Like DNA methylation, histone acetylation, and histone phosphorylation, histone methylation is plastically regulated in the rat hippocampus, in response to contextual fear conditioning $(52,74)$. Histone H3 lysine 4 trimethylation (H3K4me3), an activating modification, was found to be increased in the hippocampus $1 \mathrm{~h}$ after fear conditioning and returned to base line levels at $24 \mathrm{~h}$ after fear conditioning. Interestingly, heterozygous knockout mice, with loss of the H3K4-specific HMT Mll1, have defects in contextual fear conditioning (52) and heterozygous mutations in the two human homologues, MLL2 and MLL3, cause ID $(69,73)$. Thus, H3K4me3 appears to be an important regulator of brain function in animal models and human disease.

Histone 3 lysine 9 dimethylation (H3K9me2), a repressive modification, is also regulated in the rat brain in response to contextual fear conditioning $(52,74)$. H3K9me2 increases in the hippocampus $1 \mathrm{~h}$ after contextual fear conditioning, however, this increase is also observed in response to context alone $(52,74)$. In contrast, in the entorhinal cortex (EC), H3K9me2 was specifically increased in response to fear conditioning and not context alone (74). At $24 \mathrm{~h}$ after contextual fear conditioning, H3K9me2 decreases in the hippocampus, but remains unchanged in the EC. Thus, H3K9me2 is dynamically regulated in different ways in different brain regions in response to fear conditioning. Accordingly, pharmacological inhibition of H3K9me2 in different brain regions has different effects on contextual fear conditioning; hippocampal inhibition results in a loss of LTM, while EC inhibition results in increased LTM (74). These studies demonstrate a complex and dynamic role for H3K9me2 in different regions of the rat brain during learning and memory formation.

In humans, heterozygous mutations in the EHMT1 gene cause ID (68). EHMT1 and its paralog G9a form a complex that is important for H3K9me2 formation (75). In mice, heterozygous loss of Ehmt1 in whole animals and homozygous loss of Ehmt1 in the adult brain, causes a range of behavioral defects including reduced exploratory behavior and locomotion in response to a novel context $(76,77)$. Postnatal loss of Ehmt1 in excitatory neurons also caused defects in cued fear conditioning, sucrose preference, and the behavioral response to caffeine (77). The fruit fly, Drosophila melanogaster, contains a single ortholog of G9a and EHMT1. Loss of Drosophila EHMT/G9a also causes several behavioral and cognitive defects, including altered larval locomotory behavior, loss of habituation, and defects in STM and LTM (78). These studies further underscore that $\mathrm{H} 3 \mathrm{~K} 9$ methylation is an important mechanism in cognition and behavior (Figure 1). 


\section{Targets of epigenetic control in learning and memory}

Transcription is essential for LTM and several transcription factors, including CREB, CCAAT/enhancer binding protein (C/EBP), AP-1, and nuclear factor-kappa B (NF- $\mathrm{-B})$, are known to play an important role in memory and memory associated synaptic plasticity (7). These transcription factors recruit epigenetic modifiers to their target genes, yet relatively little is known about the target genes and how they are regulated during learning and memory formation. Several studies have used a hypothesis-driven approach to identify targets of epigenetic regulation, focusing on genes that are known to be regulated by CREB signaling in response to neuronal activity or learning $(47,48,54)$. One of the best characterized of these targets is the brain derived neurotrophic factor (BDNF), a small secreted protein that regulates synaptic activity by binding to $\mathrm{TkrB}$ receptors and activating downstream signaling pathways (80). BDNF is required in mice for normal LTP and has been implicated in memory acquisition and consolidation in the hippocampus and/or amygdala, using a variety of learning paradigms [for reviews of BDNF and its role in memory see (79-81)]. $B D N F$ gene transcription is regulated in response to neuronal activity and several studies suggest that this plasticity is dependent on epigenetic factors. Induction of neuronal depolarization in mouse embryonic cortical cultures resulted in increased $B D N F$ expression, decreased DNA methylation within the $B D N F$ promoter, and dissociation of a MeCP2-containing protein complex from the promoter (82). Expression of $B D N F$ RNA is also induced in the rat hippocampus in response to contextual fear conditioning and this change correlated with a loss of DNA methylation in the $B D N F$ regulatory region (26). Interestingly, learning induced changes in $B D N F$ promoter methylation and expression are dependent on functional NMDAR, showing that epigenetic alterations are induced by signaling pathways with a known role in learning and memory (26). In addition, alterations in histone methylation, and/or histone acetylation, have been observed in the $B D N F$ regulatory region in response to contextual fear conditioning $(26,52,83)$, spatial memory consolidation (46), and during age dependent cognitive decline (55). It has also been shown that HDAC2 can bind to the $B D N F$ promoter and that knockout or overexpression of HDAC2 in neurons leads to decreased or increased histone acetylation at the $B D N F$ promoter, respectively (47). Altered HDAC2 binding and histone acetylation in the BDNF promoter was also observed in a mouse model for Alzheimer's disease, suggesting that BDNF may be misregulated in neurodegenerative disease (54).
Analysis of specific target genes has revealed the complexity of epigenetic regulation in space and time during learning and memory. For example, the reelin gene shows altered patterns of epigenetic regulation in different brain regions. Contextual fear conditioning causes induced expression of reelin and reduced DNA methylation in its promoter in the hippocampus $1 \mathrm{~h}$ after training (25), while at the same time point, DNA methylation is increased in the reelin promoter in the cortex (31). The timing of epigenetic regulation can also vary from gene to gene. For example, reelin and other genes such as the memory suppressor, $P P 1$ (protein phosphatase 1), are transiently regulated during memory formation, showing altered epigenetic marks $1 \mathrm{~h}$ after fear conditioning, but not after $24 \mathrm{~h}$ (31). In contrast, other genes, such as the memory suppressor calcineurin, show a very stable regulation that begins $1 \mathrm{~h}$ after fear conditioning and persists for many days (31). These studies reveal that epigenetic alterations occur at specific genes during learning and memory, but also underscore the complexity of the brain, by demonstrating that specific genes are regulated in different ways in different brain regions at different time points during learning and memory formation.

Analysis of individual candidate target genes provides an excellent model for how genes may be regulated by epigenetic processes during learning and memory. However, these studies do not reveal the true mechanism or extent of gene regulation in learning and memory. Some studies have used a genome wide approach to determine how epigenetic regulators influence gene expression in the brain $(30,57,64,77,78)$. Genome wide mRNA profiling has been performed in animals that have mutations in epigenetic regulators that are known to cause learning and memory defects. Some 200 genes were shown to be differentially expressed in the forebrain of mice with brain-specific mutations in $P P 1$ (64). Interestingly, several of the misregulated genes are known to be involved in learning and memory and/or had target consensus sequences for early growth response 1 (Egr1) and C/EBP, transcription factors known to be important for memory formation. This suggests that memory defects in PP1 mutant mice are due to transcriptional mis-regulation of specific learning and memory pathways. In contrast, genome wide expression analysis in the forebrain of mice with mutations in Dnmt1 and Dnmt3a revealed upregulation of many genes involved in immunity (30). Interestingly, some of these immune genes can be directly linked to learning and memory processes, however, in general, these results would suggest that Dnmts are normally required for the suppression of these immune genes during steady state brain functioning. Analysis of gene 
expression in different brain regions of mice with mutations in the histone methyltransferases EHMT1/GLP and G9a revealed a similar scenario, where a few genes that are normally repressed in adult neurons were activated (77). This also suggested that learning and memory may be disrupted by inappropriate activation of genes in the brain. Genome wide analysis of EHMT/G9a target genes in a Drosophila model with cognitive defects, revealed enrichment for neuronal genes with known roles in learning and memory, suggesting that G9a does have the potential to target more specific learning and memory processes (78). However, it remains to be seen whether Drosophila EHMT/G9a target genes are misregulated in the brain during learning and memory.

In a study investigating age dependent cognitive decline, it was shown that hundreds of genes were differentially expressed in the hippocampus of young mice in response to fear conditioning, while in older mice, with decreased cognitive ability, this differential regulation of gene expression in response to fear conditioning was lost (57). The lack of learning-induced differential gene expression in older animals was shown to be associated, in part, with alterations in histone H4K12 acetylation. Some of the differentially regulated genes reported by Peleg et al. (57), such as formin 2 (Fmn2), are known to be important for synaptic plasticity. However, this genome wide approach did not detect changes in some of the most studied plasticity genes, like $B D N F$. This demonstrates the potential of genome-wide analysis, in contrast to candidate gene selection, for non-biased identification of novel learning and memory-regulated genes that are relevant to cognitive phenotypes in animal models of human cognitive dysfunction.

\section{Nuclear receptor signaling as an epigenetic mechanism in underlying human cognitive function}

In several recent studies investigating genetic causes of ID and autism, mutations have been identified in epigenetic regulators with strong connections to nuclear hormone receptors (Figure 2). Nuclear receptors are a class of transcription factor that is activated after binding to a ligand, often a hormone, which causes relocalization to the nucleus and rapid induction of gene expression. There are over 50 types of nuclear receptor identified in mammals and for most of these the activating ligand is unknown.
Nuclear receptors rely on epigenetic modifications in order to optimally induce changes in gene expression (84). One common theme in nuclear receptor mediated transcriptional activation is the requirement for SWI/SNF ATPase chromatin remodeling, which serves to rearrange nucleosomes in order to optimize transcriptional activation (Figure 1) (84). Recently, mutations have been identified in many members of the SWI/SNF complex in individuals with Coffin Siris syndrome (CSS), a form of severe ID (Figure 2). In total, mutations in six SWI/SNF complex members including SWI/SNF related, matrix associated, actin dependent regulator of chromatin, subfamily $B$, member 1 (SMARCB1), SMARCA4, SMARCA2, SMARCE1, $A T$ rich interactive domain $1 A$ (ARID1A) and ARID1B, were identified in individuals with CSS $(85,86)$. Mutations in this complex are not exclusive to CSS, since mutations in SMARCA2, SMARCB1, and ARID1B have also been identified in other forms of syndromic ID and autism $(73,87-89)$ (Figure 2).

Mutations in nuclear receptor related chromatin modifiers were also identified in a group of individuals with Kleefstra syndrome phenotypic spectrum (KSS), a form of ID that is accompanied by childhood hypotonia and distinct facial features (73). Epigenetic regulators disrupted in KSS individuals include the SWI/SNF member SMARCB1, the histone methyltransferase MLL3, and the nuclear receptor subfamily 1, group I, member 3 (NR1I3), also known as the constitutive androstane receptor (CAR) (73) (Figure 2). MLL3 trimethylates histone H3 at lysine 4 (H3K4me3) and is a critical member of the activating signal cointegrator-2 (ASC-2) complex (ASCOM), a large protein complex that is essential for transcriptional activation by many different nuclear receptors, including NR1I3 (Figure 1) (90-96). MLL3 and SMARCB1 have been shown to interact directly, and this interaction is essential for the co-recruitment of ASCOM and SWI/SNF complexes to nuclear receptor target genes (92). The MLL3 paralog MLL2 is also involved in human cognition, since it was shown to be disrupted in yet another multisystem disorder with the presence of ID, Kabuki syndrome (69) (Figure 2). NR113 has not been studied in a neuronal context, however it is expressed in the brain $(97,98)$ and the Drosophila homolog, the ecdysone receptor (EcR), and has been shown to have a specific role in LTM (99). These studies suggest that the epigenetic machinery surrounding nuclear receptor mediated transcription is important in human cognition and disruption of this machinery can lead to different forms of ID. Interestingly, some of these same molecular components, including ARID1B (SWI/SNF complex), MLL3, and the nuclear receptor subfamily 4 , group A, member 


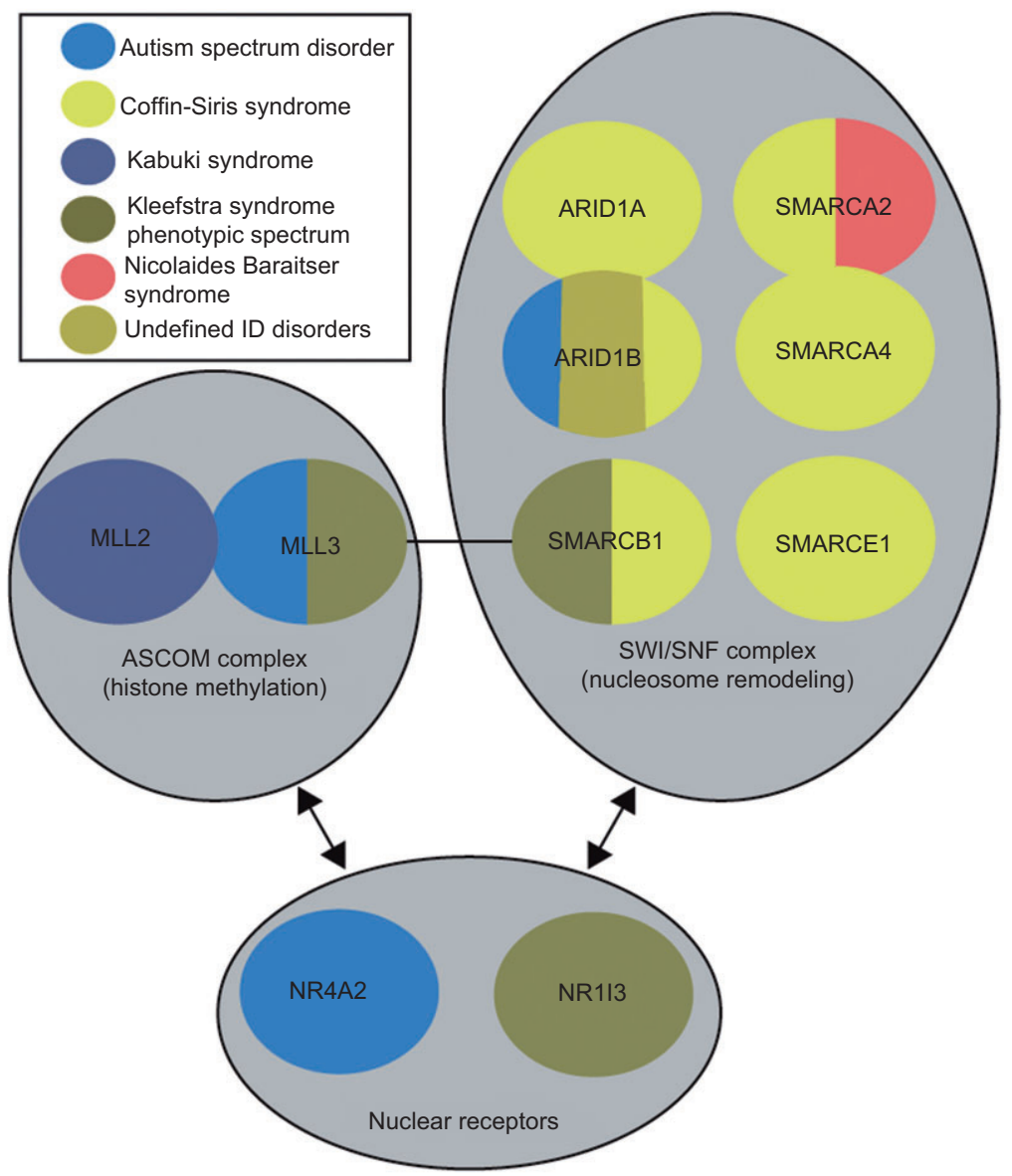

Figure 2 Nuclear receptor associated chromatin modification complexes in human cognitive disorders.

Members of the SWI/SNF complex the ASCOM complex and nuclear receptors that are implicated in human cognitive disorders (intellectual disability or autism) are indicated. A known direct protein-protein interaction between MLL3 and SMARCB1 is indicated (black line) (93). Paralogs are depicted as overlapping circles. Only complex members implicated in cognitive disorders are shown.

2 (NR4A2), have also been associated with autism (Figure 2) (87).

Although the role of nuclear hormone receptor mediated epigenetic modifications in learning and memory is still not well understood, it has long been known that hormones are important in regulating cognitive function. Glucocorticoid hormones are known to be essential for enhanced memory consolidation during stress (100). Glucocorticoids are released in response to stress and act by binding the glucocorticoid receptor (GR), a classic nuclear receptor, which relies on SWI/SNF signaling and other epigenetic regulators to induce changes in gene transcription (Figure 1) (100). GR may also influence learning-mediated epigenetic changes, through its role in ERK/MSK signaling (Figure 1). GR is required for LTM in the forced swim test, which is a stress-associated form of learning and memory requiring glucocorticoid activity in the dentate gyrus. GR was shown to bind directly to activated ERK and MSK in response to forced swimming and was required for increased MSK activation and downstream H3S10 phosphorylation in response to forced swimming (101). Estrogen is also known to be involved in human cognition (102), and the orphan nuclear receptor NR4a is known to be induced during memory consolidation in mice, and members of this receptor family have been implicated in autism $(87,103)$. Future studies will reveal the extent to which different nuclear receptors are able to mediate alterations to the chromatin landscape during learning and memory.

\section{Summary and future challenges}

Over the last decade, it has become clear that epigenetic modification of chromatin structure is essential in the control of neuronal plasticity in learning and memory. Despite these advances, we are still far from 
understanding how chromatin modifications help to shape neuronal circuits that encode memory. One of the challenges in addressing this issue is the fact that individual memories are likely stored within a small subset of neurons, which make up only a fraction of those that are normally obtained for molecular analysis. This dilutes the relevant neurons, making it difficult to identify a molecular signature associated with learning and memory. In order to identify epigenetic changes that encode memory, we must first isolate the relevant neuronal circuit in which that memory is stored. This presents a significant challenge both in obtaining the right material at the right time, and in obtaining enough material for downstream molecular analysis. A second major challenge is to move from epigenetic analysis of specific candidate target genes, to analysis of the entire epigenome during the process of learning and memory. Genome-wide analysis of the epigenetic landscape during learning and memory may reveal novel mechanisms in learning and memory and provide a more comprehensive view of the molecular mechanisms underlying cognition. Finally, a refined understanding of epigenetic mechanisms in cognition may help to conceptualize strategies for cognitive enhancement in individuals with cognitive disorders. This idea is reinforced by the use of HDAC inhibitors to improve cognition in animal models with cognitive defects. Thus, further analysis of epigenetic mechanisms at work in the nervous system will advance our knowledge of basic neuroscience, and may contribute to the discovery of new treatments for cognitive disorders, such as ID, neurodegenerative diseases, age dependent cognitive decline, and autism.

Acknowledgments: I would like to thank Annette Schenck, Hans van Bokhoven, and Nael Nadif Kasri for comments on the manuscript.

Received June 25, 2012; accepted September 13, 2012

\section{References}

1. Johansen JP, Cain CK, Ostroff LE, LeDoux JE. Molecular mechanisms of fear learning and memory. Cell 2011; 147 : 509-24.

2. Dunning J, During MJ. Molecular mechanisms of learning and memory. Expert Rev Mol Med 2003; 5: 1-11.

3. Morris RGM. Spatial localization does not require the presence of local cues. Learn Motiv 1981; 12: 239-60.

4. Broadbent NJ, Gaskin S, Squire LR, Clark RE. Object recognition memory and the rodent hippocampus. Learn Memory 2009; 17: 5-11.

5. Siegel RW, Hall JC. Conditioned responses in courtship behavior of normal and mutant Drosophila. Proc Natl Acad Sci USA 1979; 76: 3430-4.

6. Lisman J, Yasuda R, Raghavachari S. Mechanisms of CaMKII action in long-term potentiation. Nat Rev Neurosci 2012; 13: 169-82.

7. Alberini CM. Transcription factors in long-term memory and. synaptic plasticity. Physiol Rev 2009; 89: 121-45.

8. Frank DA, Greenberg ME. CREB: a mediator of long-term memory. from mollusks to mammals. Cell 1994; 79: 5-8.

9. Lubin FD, Gupta S, Parrish RR, Grissom NM, Davis RL. Epigenetic mechanisms: critical contributors to long-term memory formation. Neurosci 2011; 17: 616-32.

10. Day JJ, Sweatt JD. Epigenetic mechanisms in cognition. Neuron 2011; 70: 813-29.

11. Slack JMW. Conrad Hal Waddington: the last Renaissance biologist? Nat Rev Genet 2002; 3: 889-95.

12. Reik W. Stability and flexibility of epigenetic gene regulation in mammalian development. Nature 2007; 447: 425-32.

13. Kouzarides T. Chromatin modifications and their function. Cell 2007; 128: 693-705.

14. Wu JI, Lessard J, Crabtree GR. Understanding the words of chromatin regulation. Cell 2009; 136: 200-6.
15. Suganuma T, Workman JL. Signals and combinatorial functions of histone modifications. Annu Rev Biochem 2011; 80: 473-99.

16. Attwood JT, Yung RL, Richardson BC. DNA methylation and the regulation of gene transcription. Cell Mol Life Sci 2002; 59: 241-57.

17. Hellman A, Chess A. Gene body-specific methylation on the active $X$ chromosome. Science 2007; 315: 1141-3.

18. Wu H, Coskun V, Tao J, Xie W, Ge W, Yoshikawa K, Li E, Zhang Y, Sun YE. Dnmt3a-dependent nonpromoter DNA methylation facilitates transcription of neurogenic genes. Science 2010; 329: 444-8.

19. Chahrour M, Jung SY, Shaw C, Zhou X, Wong STC, Qin J, Zoghbi HY. MeCP2, a key contributor to neurological disease, activates and represses transcription. Science 2008; 320: 1224-9.

20. Amir RE, Van den Veyver IB, Wan M, Tran CQ, Francke U, Zoghbi HY. Rett syndrome is caused by mutations in X-linked MECP2, encoding methyl-CpG-binding protein 2. Nat Genet 1999; 23: $185-8$.

21. Xu GL, Bestor TH, Bourc'his D, Hsieh CL, Tommerup N, Bugge M, Hulten M, Qu X, Russo JJ, Viegas-Péquignot E. Chromosome instability and immunodeficiency syndrome caused by mutations in a DNA methyltransferase gene. Nature 1999; 402: 187-91.

22. Fuso A, Nicolia V, Cavallaro RA, Ricceri L, D’Anselmi F, Coluccia P, Calamandrei G, Scarpa S. B-vitamin deprivation induces hyperhomocysteinemia and brain S-adenosylhomocysteine, depletes brain S-adenosylmethionine, and enhances PS1 and BACE expression and amyloid-beta deposition in mice. Mol Cell Neurosci 2008; 37: 731-46.

23. Fuso A, Nicolia V, Pasqualato A, Fiorenza MT, Cavallaro RA, Scarpa S. Changes in Presenilin 1 gene methylation pattern in 
diet-induced B vitamin deficiency. Neurobiol Aging 2011; 32: 187-99.

24. Fuso A, Nicolia V, Cavallaro RA, Scarpa S. DNA methylase and demethylase activities are modulated by one-carbon metabolism in Alzheimer's disease models. J Nutr Biochem 2011; 22: 242-51.

25. Miller CA, Sweatt JD. Covalent modification of DNA regulates memory formation. Neuron 2007; 53: 857-69.

26. Lubin FD, Roth TL, Sweatt JD. Epigenetic regulation of bdnf gene transcription in the consolidation of fear memory. J Neurosci 2008; 28: 10576-86.

27. Guo JU, Ma DK, Mo H, Ball MP, Jang M-H, Bonaguidi MA, Balazer JA, Eaves HL, Xie B, Ford E, Zhang K, Ming G-L, Gao Y, Song H. Neuronal activity modifies the DNA methylation landscape in the adult brain. Nat Neurosci 2011; 14: 1345-51.

28. Levenson JM. Evidence that DNA (cytosine-5) methyltransferase regulates synaptic plasticity in the hippocampus. J Biol Chem 2006; 281: 15763-73.

29. Bliss TVP, Cooke SF. Long-term potentiation and long-term depression: a clinical perspective. Clinics 2011; 66: 3-17.

30. Feng J, Zhou Y, Campbell SL, Le T, Li E, Sweatt JD, Silva AJ, Fan G. Dnmt1 and Dnmt3a maintain DNA methylation and regulate synaptic function in adult forebrain neurons. Nat Neurosci 2010; 13: 423-30.

31. Miller CA, Gavin CF, White JA, Parrish RR, Honasoge A, Yancey CR, Rivera IM, Rubio MD, Rumbaugh G, Sweatt JD. Cortical DNA methylation maintains remote memory. Nat Neurosci 2010; 13 : 664-6.

32. Weaver ICG, Cervoni N, Champagne FA, D’Alessio AC, Sharma S, Seckl JR, Dymov S, Szyf M, Meaney MJ. Epigenetic programming by maternal behavior. Nat Neurosci 2004; 7: 847-54.

33. McGowan PO, Sasaki A, D’Alessio AC, Dymov S, Labonté B, Szyf M, Turecki G, Meaney MJ. Epigenetic regulation of the glucocorticoid receptor in human brain associates with childhood abuse. Nat Neurosci 2009; 12: 342-8.

34. Davie JR, Chadee DN. Regulation and regulatory parameters of histone modifications. J Cell Biochem (Suppl) 1998; 30-31: 203-13.

35. MacDonald VE, Howe LJ. Histone acetylation: where to go and. how to get there. Epigenetics 2009; 4: 139-43.

36. Petrij F, Giles RH, Dauwerse HG, Saris JJ, Hennekam RC, Masuno M, Tommerup N, van Ommen GJ, Goodman RH, Peters DJ. Rubinstein-Taybi syndrome caused by mutations in the transcriptional co-activator CBP. Nature 1995; 376: 348-51.

37. Williams SR, Aldred MA, Kaloustian Der VM, Halal F, Gowans G, McLeod DR, Zondag S, Toriello HV, Magenis RE, Elsea $\mathrm{SH}$. Haploinsufficiency of HDAC 4 causes brachydactyly mental retardation syndrome, with brachydactyly type $\mathrm{E}$, developmental delays, and behavioral problems. Am J Hum Genet 2010; 87: 219-28.

38. Roelfsema JH, White SJ, Ariyürek Y, Bartholdi D, Niedrist D, Papadia F, Bacino CA, Dunnen den JT, van Ommen G-JB, Breuning MH, Hennekam RC, Peters DJM. Genetic heterogeneity in Rubinstein-Taybi syndrome: mutations in both the CBP and EP300 genes cause disease. Am J Hum Genet 2005; 76: 572-80.

39. Chwang WB, O'Riordan KJ, Levenson JM, Sweatt JD. ERK/MAPK regulates hippocampal histone phosphorylation following contextual fear conditioning. Learn Memory 2006; 13: 322-8.
40. Levenson JM, O’Riordan KJ, Brown KD, Trinh MA, Molfese DL, Sweatt JD. Regulation of histone acetylation during memory formation in the hippocampus. J Biol Chem 2004; 279: 40545-59.

41. Alarcón JM, Malleret G, Touzani K, Vronskaya S, Ishii S, Kandel ER, Barco A. Chromatin acetylation, memory, and LTP are impaired in $\mathrm{CBP}^{+/-}$mice. Neuron 2004; 42: 947-59.

42. Oike Y, Hata A, Mamiya T, Kaname T, Noda Y, Suzuki M, Yasue H, Nabeshima T, Araki K, Yamamura K. Truncated CBP protein leads to classical Rubinstein-Taybi syndrome phenotypes in mice: implications for a dominant-negative mechanism. Hum Mol Genet 1999; 8: 387-96.

43. Bourtchouladze R, Lidge R, Catapano R, Stanley J, Gossweiler S, Romashko D, Scott R, Tully T. A mouse model of Rubinstein-Taybi syndrome: defective long-term memory is ameliorated by. inhibitors of phosphodiesterase 4. Proc Natl Acad Sci USA 2003; 100: 10518-22.

44. Wood MA, Attner MA, Oliveira AMM, Brindle PK, Abel T. A transcription factor-binding domain of the coactivator CBP is essential for long-term memory and the expression of specific. target genes. Learn Memory 2006; 13: 609-17.

45. Korzus E, Rosenfeld MG, Mayford M. CBP histone acetyltransferase activity is a critical component of memory consolidation. Neuron 2004; 42: 961-72.

46. Bousiges O, Vasconcelos AP de, Neidl R, Cosquer B, Herbeaux K, Panteleeva I, Loeffler J-P, Cassel J-C, Boutillier A-L. Spatial memory consolidation is associated with induction of several lysine-acetyltransferase (histone acetyltransferase) expression levels and $\mathrm{H} 2 \mathrm{~B} / \mathrm{H} 4$ acetylation-dependent transcriptional events in the rat hippocampus. Neuropsychopharmacol 2010; 35: 2521-37.

47. Guan J-S, Haggarty SJ, Giacometti E, Dannenberg J-H, Joseph N, Gao J, Nieland TJF, Zhou Y, Wang X, Mazitschek R, Bradner JE, DePinho RA, Jaenisch R, Tsai L-H. HDAC2 negatively regulates memory formation and synaptic plasticity. Nature 2009; 459: $55-60$.

48. Vecsey CG, Hawk JD, Lattal KM, Stein JM, Fabian SA, Attner MA, Cabrera SM, McDonough CB, Brindle PK, Abel T, Wood MA. Histone deacetylase inhibitors enhance memory and synaptic. plasticity via CREB: CBP-dependent transcriptional activation. J Neurosci 2007; 27: 6128-40.

49. Bredy TW, Barad M. The histone deacetylase inhibitor valproic acid enhances acquisition, extinction, and reconsolidation of conditioned fear. Learn Memory 2008; 15: 39-45.

50. Stafford JM, Raybuck JD, Ryabinin AE, Lattal KM. Increasing histone acetylation in the hippocampus-infralimbic network. enhances fear extinction. Biol Psychiat 2012; 72: 25-33.

51. Chwang WB, Arthur JS, Schumacher A, Sweatt JD. The nuclear kinase mitogen- and stress-activated protein kinase 1 regulates hippocampal chromatin remodeling in memory formation. J Neurosci 2007; 27: 12732-42.

52. Gupta S, Kim SY, Artis S, Molfese DL, Schumacher A, Sweatt JD, Paylor RE, Lubin FD. Histone methylation regulates memory. formation. J Neurosci 2010; 30: 3589-99.

53. Fass DM, Reis SA, Ghosh B, Hennig KM, Joseph NF, Zhao W-N, Nieland TJF, Guan J-S, Groves Kuhnle CE, Tang W, Barker DD, Mazitschek R, Schreiber SL, Tsai L-H, Haggarty SJ. Crebinostat: a novel cognitive enhancer that inhibits histone deacetylase activity and modulates chromatin-mediated neuroplasticity. Neuropharmacology 2012; 64: 81-96. 
54. Gräff J, Rei D, Guan J-S, Wang W-Y, Seo J, Hennig KM, Nieland TJF, Fass DM, Kao PF, Kahn M, Su SC, Samiei A, Joseph N, Haggarty SJ, Delalle I, Tsai L-H. An epigenetic blockade of cognitive functions in the neurodegenerating brain. Nature 2012; 483: 222-6.

55. Zeng Y, Tan M, Kohyama J, Sneddon M, Watson JB, Sun YE, Xie C-W. Epigenetic enhancement of BDNF signaling rescues synaptic plasticity in aging. J Neurosci 2011; 31: 17800-10.

56. Castellano JF, Fletcher BR, Kelley-Bell B, Kim DH, Gallagher M, Rapp PR. Age-related memory impairment is associated. with disrupted multivariate epigenetic coordination in the hippocampus. PLoS ONE 2012; 7: e33249.

57. Peleg S, Sananbenesi F, Zovoilis A, Burkhardt S, Bahari-Javan S, Agis-Balboa RC, Cota P, Wittnam JL, Gogol-Doering A, Opitz L, Salinas-Riester G, Dettenhofer M, Kang H, Farinelli L, Chen W, Fischer A. Altered histone acetylation is associated with age-dependent memory impairment in mice. Science 2010; 328: 753-6.

58. Kilgore M, Miller CA, Fass DM, Hennig KM, Haggarty SJ, Sweatt JD, Rumbaugh G. Inhibitors of class 1 histone deacetylases reverse contextual memory deficits in a mouse model of Alzheimer's disease. Neuropsychopharmacology 2009; 35: 870-80.

59. Fischer A, Sananbenesi F, Wang X, Dobbin M, Tsai L-H. Recovery of learning and memory is associated with chromatin remodelling. Nature 2007; 447: 178-82.

60. Ricobaraza A, Cuadrado-Tejedor M, Pérez-Mediavilla A, Frechilla D, Del Río J, García-Osta A. Phenylbutyrate ameliorates cognitive deficit and reduces tau pathology in an Alzheimer's disease mouse model. Neuropsychopharmacology 2009; 34: 1721-32.

61. Green KN, Steffan JS, Martinez-Coria H, Sun X, Schreiber SS, Thompson LM, LaFerla FM. Nicotinamide restores cognition in Alzheimer's disease transgenic mice via a mechanism involving sirtuin inhibition and selective reduction of Thr231-phosphotau. J Neurosci 2008; 28: 11500-10.

62. Banerjee T, Chakravarti D. A peek into the complex realm of. histone phosphorylation. Mol Cell Biol 2011; 31: 4858-73.

63. Koshibu K, Gräff J, Mansuy IM. Nuclear protein phosphatase-1: an epigenetic regulator of fear memory and amygdala long-term potentiation. Neuroscience 2011; 173: 30-6.

64. Gräff J, Koshibu K, Jouvenceau A, Dutar P, Mansuy IM. Protein phosphatase 1-dependent transcriptional programs for long-term memory and plasticity. Learn Memory 2010; 17 : 355-63.

65. Koshibu K, Gräff J, Beullens M, Heitz FD, Berchtold D, Russig $\mathrm{H}$, Farinelli M, Bollen M, Mansuy IM. Protein phosphatase 1 regulates the histone code for long-term memory. J Neurosci 2009; 29: 13079-89.

66. Barski A, Cuddapah S, Cui K, Roh T-Y, Schones DE, Wang Z, Wei G, Chepelev I, Zhao K. High-resolution profiling of histone methylations in the human genome. Cell 2007; 129: 823-37.

67. Jensen LR, Amende M, Gurok U, Moser B, Gimmel V, Tzschach A, Janecke AR, Tariverdian G, Chelly J, Fryns J-P, Van Esch H, Kleefstra T, Hamel B, Moraine C, Gecz J, Turner G, Reinhardt R, Kalscheuer VM, Ropers H-H, Lenzner S. Mutations in the JARID1C gene, which is involved in transcriptional regulation and chromatin remodeling, cause $\mathrm{X}$-linked mental retardation. Am J Hum Genet 2005; 76: 227-36.

68. Kleefstra T, Brunner HG, Amiel J, Oudakker AR, Nillesen WM, Magee A, Geneviève D, Cormier-Daire V, Van Esch H, Fryns
J-P, Hamel BCJ, Sistermans EA, de Vries BBA, van Bokhoven $\mathrm{H}$. Loss-of-function mutations in euchromatin histone methyl transferase 1 (EHMT1) cause the 9q34 subtelomeric deletion syndrome. Am J Hum Genet 2006; 79: 370-7.

69. Ng SB, Bigham AW, Buckingham KJ, Hannibal MC, McMillin MJ, Gildersleeve HI, Beck AE, Tabor HK, Cooper GM, Mefford HC, Lee C, Turner EH, Smith JD, Rieder MJ, Yoshiura K-I, Matsumoto N, Ohta T, Niikawa N, Nickerson DA, Bamshad MJ, Shendure J. Exome sequencing identifies MLL2 mutations as a cause of Kabuki syndrome. Nat Genet 2010; 42: 790-3.

70. Laumonnier F, Holbert S, Ronce N, Faravelli F, Lenzner S, Schwartz CE, Lespinasse J, Van Esch H, Lacombe D, Goizet C, Phan-Dinh Tuy F, van Bokhoven H, Fryns J-P, Chelly J, Ropers $\mathrm{H}-\mathrm{H}$, Moraine C, Hamel BCJ, Briault S. Mutations in PHF8 are associated with $\mathrm{X}$ linked mental retardation and cleft lip/cleft palate. J Med Genet 2005; 42: 780-6.

71. Kurotaki N, Imaizumi K, Harada N, Masuno M, Kondoh T, Nagai T, Ohashi H, Naritomi K, Tsukahara M, Makita Y, Sugimoto T, Sonoda T, Hasegawa T, Chinen Y, Tomita Ha H-A, Kinoshita A, Mizuguchi T, Yoshiura Ki K-I, Ohta T, Kishino T, Fukushima Y, Niikawa N, Matsumoto N. Haploinsufficiency of NSD1 causes Sotos syndrome. Nat Genet 2002; 30: 365-6.

72. Douglas J, Hanks S, Temple IK, Davies S, Murray A, Upadhyaya M, Tomkins S, Hughes HE, Cole TRP, Rahman N. NSD1 mutations are the major cause of Sotos syndrome and occur in some cases of Weaver syndrome but are rare in other overgrowth phenotypes. Am J Hum Genet 2003; 72: 132-43.

73. Kleefstra T, Kramer JM, Neveling K, Willemsen MH, Koemans TS, Vissers LELM, Wissink-Lindhout W, Fenckova M, van den Akker WMR, Kasri NN, Nillesen WM, Prescott T, Clark RD, Devriendt K, van Reeuwijk J, de Brouwer APM, Gilissen C, Zhou H, Brunner HG, Veltman JA, Schenck A, van Bokhoven H. Disruption of an EHMT1-associated chromatin-modification module causes intellectual disability. Am J Hum Genet 2012; 91: 73-82.

74. Gupta-Agarwal S, Franklin AV, DeRamus T, Wheelock M, Davis RL, McMahon LL, Lubin FD. G9a/GLP histone lysine dimethyltransferase complex activity in the hippocampus and. the entorhinal cortex is required for gene activation and. silencing during memory consolidation. J Neurosci 2012; 32: 5440-53.

75. Tachibana M. G9a histone methyltransferase plays a dominant role in euchromatic histone $\mathrm{H} 3$ lysine 9 methylation and is essential for early embryogenesis. Gene Dev 2002; 16 : 1779-91.

76. Balemans MCM, Huibers MMH, Eikelenboom NWD, Kuipers AJ, van Summeren RCJ, Pijpers MMCA, Tachibana M, Shinkai Y, van Bokhoven H, Van der Zee CEEM. Reduced exploration, increased anxiety, and altered social behavior: autistic-like features of euchromatin histone methyltransferase 1 heterozygous knockout mice. Behav Brain Res 2010; 208: 47-55.

77. Schaefer A, Sampath SC, Intrator A, Min A, Gertler TS, Surmeier DJ, Tarakhovsky A, Greengard P. Control of cognition and adaptive behavior by the GLP/G9a epigenetic suppressor complex. Neuron 2009; 64: 678-91.

78. Kramer JM, Kochinke K, Oortveld MAW, Marks H, Kramer D, de Jong EK, Asztalos Z, Westwood JT, Stunnenberg HG, Sokolowski MB, Keleman K, Zhou H, van Bokhoven H, Schenck A. Epigenetic regulation of learning and memory by Drosophila EHMT/G9a. PLoS Biol 2011; 9: e1000569. 
79. West AE, Chen WG, Dalva MB, Dolmetsch RE, Kornhauser JM, Shaywitz AJ, Takasu MA, Tao X, Greenberg ME. Calcium regulation of neuronal gene expression. Proc Natl Acad Sci USA 2001; 98: 11024-31.

80. Lu Y, Christian K, Lu B. BDNF: a key regulator for protein synthesis-dependent LTP and long-term memory? Neurobiol Learn Mem 2008; 89: 312-23.

81. Bekinschtein P, Cammarota M, Izquierdo I, Medina JH. BDNF and memory formation and storage. Neuroscientist 2008; 14 : 147-56.

82. Martinowich K. DNA methylation-related chromatin remodeling in activity-dependent Bdnf gene regulation. Science 2003; 302: 890-3.

83. Bredy TW, Wu H, Crego C, Zellhoefer J, Sun YE, Barad M. Histone modifications around individual BDNF gene promoters in prefrontal cortex are associated with extinction of conditioned. fear. Learn Memory 2007; 14: 268-76.

84. Wiench M, Miranda TB, Hager GL. Control of nuclear receptor function by local chromatin structure. FEBS J 2011; 278 : 2211-30.

85. Tsurusaki Y, Okamoto N, Ohashi H, Kosho T, Imai Y, Hibi-Ko Y, Kaname T, Naritomi K, Kawame H, Wakui K, Fukushima Y, Homma T, Kato M, Hiraki Y, Yamagata T, Yano S, Mizuno S, Sakazume S, Ishii T, Nagai T, Shiina M, Ogata K, Ohta T, Niikawa N, Miyatake S, Okada I, Mizuguchi T, Doi H, Saitsu H, Miyake $\mathrm{N}$, Matsumoto N. Mutations affecting components of the SWI/ SNF complex cause Coffin-Siris syndrome. Nat Genet 2012; 44: 376-8.

86. Santen GWE, Aten E, Sun Y, Almomani R, Gilissen C, Nielsen M, Kant SG, Snoeck IN, Peeters EAJ, Hilhorst-Hofstee Y, Wessels MW, Hollander den NS, Ruivenkamp CAL, van Ommen G-JB, Breuning $M H$, Dunnen den JT, van Haeringen A, Kriek M. Mutations in SWI/ SNF chromatin remodeling complex gene ARID1B cause Coffin-Siris syndrome. Nat Genet 2012; 44: 379-80.

87. O'Roak BJ, Vives L, Girirajan S, Karakoc E, Krumm N, Coe BP, Levy R, Ko A, Lee C, Smith JD, Turner EH, Stanaway IB, Vernot B, Malig M, Baker C, Reilly B, Akey JM, Borenstein E, Rieder MJ, Nickerson DA, Bernier R, Shendure J, Eichler EE. Sporadic autism exomes reveal a highly interconnected protein network of de novo mutations. Nature 2012; 485: 246-50.

88. Van Houdt JKJ, Nowakowska BA, Sousa SB, van Schaik BDC, Seuntjens E, Avonce N, Sifrim A, Abdul-Rahman OA, van den Boogaard M-JH, Bottani A, Castori M, Cormier-Daire V, Deardorff MA, Filges I, Fryer A, Fryns J-P, Gana S, Garavelli L, Gillessen-Kaesbach G, Hall BD, Horn D, Huylebroeck D, Klapecki J, Krajewska-Walasek M, Kuechler A, Lines MA, Maas S, Macdermot KD, McKee S, Magee A, de Man SA, Moreau Y, Morice-Picard F, Obersztyn E, Pilch J, Rosser E, Shannon N, Stolte-Dijkstra I, Van Dijck P, Vilain C, Vogels A, Wakeling E, Wieczorek D, Wilson L, Zuffardi O, van Kampen AHC, Devriendt $K$, Hennekam R, Vermeesch JR. Heterozygous missense mutations in SMARCA2 cause Nicolaides-Baraitser syndrome. Nat Genet 2012; 44: 445-9.

89. Hoyer J, Ekici AB, Endele S, Popp B, Zweier C, Wiesener A, Wohlleber E, Dufke A, Rossier E, Petsch C, Zweier M, Göhring I, Zink AM, Rappold G, Schröck E, Wieczorek D, Riess O, Engels H, Rauch A, Reis A. Haploinsufficiency of ARID1B, a member of the
SWI/SNF-A chromatin-remodeling complex, is a frequent cause of intellectual disability. Am J Hum Genet 2012; 90: 565-72.

90. Kim D-H, Lee J, Lee B, Lee JW. ASCOM controls farnesoid X receptor transactivation through its associated histone $\mathrm{H} 3$ lysine 4 methyltransferase activity. Mol Endocrinol 2009; 23: 1556-62.

91. Ananthanarayanan M, Li Y, Surapureddi S, Balasubramaniyan N, Ahn J, Goldstein JA, Suchy FJ. Histone H3K4 trimethylation by MLL3 as part of ASCOM complex is critical for NR activation of bile acid transporter genes and is downregulated in cholestasis. Am J Physiol Gastroint Liver Physiol 2011; 300: G771-81.

92. Lee S, Kim D-H, Goo YH, Lee YC, Lee S-K, Lee JW. Crucial roles for interactions between MLL3/4 and INI1 in nuclear receptor transactivation. Mol Endocrinol 2009; 23: 610-9.

93. Vicent GP, Nacht AS, Font-Mateu J, Castellano G, Gaveglia L, Ballaré C, Beato M. Four enzymes cooperate to displace histone $\mathrm{H} 1$ during the first minute of hormonal gene activation. Gene Dev 2011; 25: 845-62.

94. Johnston DM, Sedkov Y, Petruk S, Riley KM, Fujioka M, Jaynes JB, Mazo A. Ecdysone- and NO-mediated gene regulation by competing ECR/Usp and E75A nuclear receptors during Drosophila development. Mol Cell 2011; 44: 51-61.

95. Sedkov Y, Cho E, Petruk S, Cherbas L, Smith ST, Jones RS, Cherbas P, Canaani E, Jaynes JB, Mazo A. Methylation at lysine 4 of histone $\mathrm{H} 3$ in ecdysone-dependent development of Drosophila. Nature 2003; 426: 78-83.

96. Choi E, Lee S, Yeom S-Y, Kim GH, Lee JW, Kim S-W. Characterization of activating signal cointegrator-2 as a novel transcriptional coactivator of the xenobiotic nuclear receptor constitutive androstane receptor. Mol Endocrinol 2005; 19 : 1711-9.

97. Nishimura M, Naito S, Yokoi T. Tissue-specific mRNA expression profiles of human nuclear receptor subfamilies. Drug Metab Pharmacok 2004; 19: 135-49.

98. Dutheil F, Dauchy S, Diry M, Sazdovitch V, Cloarec O, Mellottée L, Bièche I, Ingelman-Sundberg M, Flinois J-P, de Waziers I, Beaune $P$, Declèves $X$, Duyckaerts $C$, Loriot $M-A$. Xenobioticmetabolizing enzymes and transporters in the normal human brain: regional and cellular mapping as a basis for putative roles in cerebral function. Drug Metab Dispos 2009; 37 : 1528-38.

99. Ishimoto H, Sakai T, Kitamoto T. Ecdysone signaling regulates the formation of long-term courtship memory in adult. Drosophila melanogaster. Proc Natl Acad Sci USA 2009; 106: 6381-6.

100. Trollope AF, Gutièrrez-Mecinas $M$, Mifsud KR, Collins A, Saunderson EA, Reul JMHM. Stress, epigenetic control of gene expression and memory formation. Exp Neurol 2012; 233: 3-11.

101. Gutièrrez-Mecinas $M$, Trollope AF, Collins $A$, Morfett $H$, Hesketh SA, Kersanté F, Reul JMHM. Long-lasting behavioral responses to stress involve a direct interaction of glucocorticoid receptors with ERK1/2-MSK1-Elk-1 signaling. Proc Natl Acad Sci USA 2011; 108: $13806-11$.

102. Luine VN. Sex steroids and cognitive function. J Neuroendocrinol 2008; 20: 866-72.

103. Hawk JD, Abel T. The role of NR4A transcription factors in memory formation. Brain Res Bull 2011; 85: 21-9. 